\title{
Applying to be 'Industrial Soldiers': The Letters of Young Women Wanting to Train as Chemistry Laboratory Technicians, 1942-1944
}

\author{
Amber Lloydlangston
}

\section{ABSTRACT}

Between 1942 and 1944, just over 100 young women from southwestern Ontario applied to, and were accepted into, one of four female chemistry laboratory technician courses held at the University of Western Ontario under the aegis of the Dominion-Provincial War Emergency Training Program. This paper constitutes a social discourse analysis of the letters written by the young women. It explores the backgrounds of the participants in the communication, as well as its social and institutional context, seeking to understand how the young women presented themselves as they sought entry into this course. Did they duplicate the discourse provided to them? They did, but only to a degree. For example, they emphasized educational attainment but did not reference patriotism and a desire to help Canada's war effort. This exercise suggests that Canada's Total War did not touch every Canadian quite as profoundly as we might believe.

\section{RÉSUMÉ}

Entre 1942 et 1944, un peu plus de 100 jeunes femmes venant du Sud-Ouest de l'Ontario posaient avec succès leur candidature à l'un des quatre cours de formation de techniciennes pour des laboratoires de chimie tenus à l'Université de Western Ontario sous l'égide du Programme de formation d'urgence en temps de guerre du Canada. Cet article présente une analyse sociale de la teneur des lettres de motivation écrites par ces jeunes femmes. L'auteure s'intéresse à la fois aux antécédents ainsi qu'à la situation sociale et académique des candidates afin de mieux comprendre comment ces jeunes femmes se sont présentées elles-mêmes en vue de leur admission à ce cours. Ont-elles reproduit le discours qui leur était suggéré? Oui, dans une certaine mesure. Par exemple, elles mettaient l'accent sur la réussite scolaire, mais elles ne faisaient aucune référence au patriotisme et au désir de contribuer à l'effort de guerre canadien. Cette étude suggère que l'effort de guerre n'affectait pas tous les Canadiens aussi profondément qu'on l'aurait cru.

"...I am extremely interested in preparing myself for a career in the Plastics or similar industry..." Miss A.

"...I have always been interested in science, and realize that this is a wonderful opportunity. At present I feel that I am not doing enough for Canada's war effort, and would appreciate an opportunity to do my part." Miss M. ${ }^{1}$ 
In late August 1942, Dr. John Aberdeen Gunton, head of the University of Western Ontario's Chemistry Department, began to compile a file of correspondence from a unique group of young women. Numbering just over 100 by the time Dr. Gunton closed the file in 1945, all of them had been accepted into one of four female chemistry laboratory technician courses offered at Western under the aegis of the Dominion-Provincial War Emergency Training Plan (WETP) between 1942 and 1944. ${ }^{2}$ Unique in that they had been accepted into the chemistry laboratory technician course when many others had been rejected, the young women were otherwise unremarkable. Most of them were schoolgirls who had been living ordinary lives in small town or rural southwestern Ontario when they applied for the course. Had Dr. Gunton not preserved the correspondence, they would have joined the thousands of other Canadian women who undertook industrial training and then worked anonymously in Canada's extensive wartime industries. But Dr. Gunton did preserve the correspondence, providing a rare glimpse into the motivations and aspirations of a particular group of young women hoping to take advantage of an unusual training opportunity. In this study, I will conduct a social discourse analysis of the young women's correspondence to better understand the nature of those aspirations and motivations. What did the young women write to try to gain acceptance into the course? Responding to a circular sent to high schools in southwestern Ontario as well as to newspaper articles published in the local press, to what extent did the young women echo the discourse provided to them? To what extent did they employ a different one in their efforts to secure admission to the course? And what does this information add to our knowledge of the experiences of Canadian women during the Second World War? Before turning to this discussion, however, I will first answer two methodological questions: 1) Why are letters relevant historical documents warranting such pointed analysis?,2) Why is social discourse analysis the appropriate tool for this exercise?

Letters, both personal missives exchanged between family and friends and more formal correspondence such as that generated by business people and diplomats, have long been used as a resource to supplement the more "official" historical record. Even as a supplementary resource, however, they have not been regarded uncritically. For some, letters have proven to be frustrating because their authors did not discuss significant historical events occurring at the time the letters were written. For others, letters are so formalized and formulaic that they reveal little of interest to the historian. Still others note their ephemeral nature; it can be difficult to locate a cache of letters, which lend themselves to historical analysis. ${ }^{3}$ Rather than viewing these as insurmountable obstacles to their use, historians of epistolary and the epistolary tradition regard them as reasons to study letters as a genre apart. For historians conducting history at the micro level, the letter is an "artefact of the past; ...the physical memory of what has gone before," something akin to oral histories. ${ }^{4}$ Unlike oral histories, though, the information communicated in letters is not coloured by the passage of time. ${ }^{5}$ This is not to say, however, that letters are unmediated; they are cultural artifacts, encoded texts, requiring an analysis of the "gendered political context of their ideological background and/or of their narrative devices." 6 That letters 
are constructed and that they are not unmediated historical artifacts is where their interest lies. By considering the relationship between the author and the recipient, by analysing the context in which they were written, by understanding the purpose for which they were written, and by analysing the language employed, that is by conducting social discourse analysis, the historian can begin to deconstruct the "fictions of the self" constructed by the authors of the letters. ${ }^{7}$

Social discourse analysis, focusing as it does on analysing the context of the communicative event, best satisfies the call of historians of epistolary and the epistolary tradition to reveal the mediated nature of letters. Letters are, after all, drafted by particular authors for a particular recipient to achieve a particular goal. This form of textual discourse takes place or is accomplished in a social situation and social discourse analysis endeavours to make explicit the different facets of that social situation. As elaborated by Teun A. van Dijk, social discourse analysis entails an investigation into the characteristics of the participants, including their gender, age, class, education, social position, ethnicity, and profession. It also includes a consideration of their social roles. Are the participants in the exchange friends or foes, powerful or powerless, dominant or dominated? ${ }^{8}$ Determining answers to these questions is important because "people adapt what they say — and how they say it, and how they interpret what others say - to at least some of their roles or identities, and to the roles of other participants." Finally, social discourse analysis also necessitates an investigation of the social, cultural, and institutional context in which the communicative event occurred. ${ }^{10}$ While this may seem straightforward, it is not. As van Dijk tellingly observes, "contexts are not objective in the sense that they consist of social facts that are understood and considered relevant in the same way by all participants. They are interpreted or constructed, and strategically and continually made relevant by and for participants." 11 As I will demonstrate in the case considered in this study, the young women applicants, Dr. Gunton, and the officials of the WETP did not view the female chemistry laboratory technician training program in the same light. While for some of the individual women and for Dr. Gunton the course offered an unparalleled opportunity for young women wishing to train for a career, for the WETP it was a response to the wartime demands of a rapidly expanding industrial sector.

\section{The Letter Writers and their Recipient}

Who were the letter writers? The young women's two most universally shared characteristics were their ethnicity and their youth. Their family names indicate that the majority were of Anglo-Saxon extraction. Certain of the young women, haling from the Kitchener-Waterloo region, had surnames that suggested that their families were, or once had been, German Mennonites. As for their age, apart from one woman, 29 years old and married, the others ranged in age from 16 to their early twenties and they were single. Their level of schooling reflects their age. Although not every applicant specified her educational attainments, ${ }^{12}$ for those who did 20 had junior and 12 senior matriculation. One, the 29-year-old, did not specify her level of schooling, emphasizing instead her seven years of laboratory experience. Another had completed 
one year of nurse's training but abandoned the course due to illness. And still another had trained as an occupational therapist. What was their social class or, more accurately, status? A careful reading of the young women's letters, combined with a review of city directories, produced information for 56 of the 103 young women or $54 \%$. Identifying occupation of the household head, in all but two instances the father, ${ }^{13}$ and looking at its position on the 1947 US National Opinion Research Center occupational prestige scale, I conclude that the majority of the young women belonged to the middle class with a few who placed on one or the other side of that position. ${ }^{14}$ The fathers' occupations included: farmer, insurance agent, purchasing agent, car salesman, and clerk. Several also worked for the Canadian National Railway and Imperial Oil although the nature of the employment was not specified. One father was a soldier as were several of the young women's brothers. Two fathers owned their own business, one being a grocer and another operating a garage, and two were managers in others' businesses. And several fathers were professionals: a pathologist, a university professor, a high school principal, and a statistician. One young woman was a graduate of Branksome Hall, a private school for girls, and so although I was unable to find information about her father, I concluded that she was the daughter of a wealthy, upper class family, a supposition confirmed in a letter of recommendation for her in which a family friend wrote: "I am particularly impressed with [her] ambition to work, rather than to follow the usual path of the idle rich." ${ }^{15}$ Finally, two young women worked to help support widowed mothers, one of whom was a teacher and the other was not employed.

Who was the recipient of these letters? Dr. John Aberdeen Gunton (1894-1973), with an undergraduate degree from McMaster University and a Ph.D. from the University of Illinois, joined the Chemistry Department at the University of Western Ontario as its head in 1923. He held this position until 1959. ${ }^{16}$ In 1942, Dr. Gunton was 48 years old and well established in his position as head of the chemistry department at Western. His gender, his age, his education, and his professional position are indicative of a considerably more elevated social status than that enjoyed by his young female correspondents. ${ }^{17}$ On multiple levels, Dr. Gunton was an authority figure. And the young women addressed him accordingly in their letters of application and confirmation of attendance, in the former hoping to gain admittance by respectfully demonstrating their suitability and in the latter respectfully expressing gratitude and a desire to perform satisfactorily. Before turning to this discussion, however, I will next consider the social and cultural and then institutional contexts of the chemistry laboratory technician program. Only then will I have assembled all of the information required to explore the letters themselves.

\section{Social and Cultural Context}

Continuing a trend that had begun in the late nineteenth century, in the interwar years, more and more young women expected to undertake paid employment between leaving school and getting married. Census data for the years 1921 to 1941 shows a growing percentage of women working between the ages of 20 to $34^{18}$ : 


\begin{tabular}{|c|c|c|}
\hline Year & Age Range: $\mathbf{2 0 - 2 4}$ & Age Range: 25-34 \\
\hline 1921 & $39.8 \%$ & $19.5 \%$ \\
\hline 1931 & $47.4 \%$ & $24.4 \%$ \\
\hline 1941 & $46.9 \%$ & $27.9 \%$ \\
\hline
\end{tabular}

The majority of these young women were employed in occupations which had been sex-typed as appropriate for women. The result was that, as Veronica StrongBoag reports, $70.9 \%$ of women were confined to "only six of the twenty-five categories covered by the census - textiles and clothing, retail and wholesale trade, education, health and welfare services, food and lodging, and personal and recreational services - in 1921, 73.2\% in 1931, and 71.98\% in 1941."19 While some of the occupations grouped within these categories were blue-collar, others were white-collar, attracting the growing numbers of women who had secured a high school or collegiate institute diploma. This employment, offering a cleaner and sometimes safer work environment and some degree of prestige did not, however, offer elevated wages or opportunities for advancement. Among these sex-segregated white collar occupations was that of chemistry laboratory technician or assistant.

Exploring the presence of women in industrial chemistry in England in the 1930s, Sally Horrocks writes: "Far from representing a triumph of feminist campaigns for equality, the entry of women into industrial science conformed instead to existing notions of what was appropriate work for women, reinforcing rather than challenging these boundaries." 20 Studying the Canadian experience, historian Peter Twohig has demonstrated that by 1942, women were well established as medical laboratory technicians. ${ }^{21}$ Similarly, my research into the scientific hierarchy within the federal Department of Agriculture in the early twentieth century has shown the same trend in the use of women as laboratory assistants/technicians in both seed and feed analysis. ${ }^{22}$ By the Second World War the work of laboratory technician and/or laboratory assistant had been sex-typed as women's work, requiring as it did attention to detail, manual dexterity, patience, and docility, attributes, which women were believed to very nearly monopolize. In both the medical laboratories and those of the Department of Agriculture, women were hired based predominantly on their correct attitudes and behaviours than on formal training. The laboratories were willing to train the women on the job. With the exigencies of war, however, industry required trained technicians and it looked the Dominion-Provincial War Emergency Training Plan to provide them.

\section{Institutional Context}

The Dominion-Provincial War Emergency Training Plan (WETP), a wartime measure, constituted a further development of pre-existing federal-provincial youth training agreements. Indeed, the federal government had a long history of supporting vocational training, dating from the 1912 Agriculture Aid Act. ${ }^{23}$ Its more immediate predecessor, however, was the Dominion-Provincial Youth Training Plan, created 
under the 1937 Unemployment and Agricultural Instruction Act, which saw a million dollars of federal funds given to the provinces to train "all young people, 18 to 30 years of age, without gainful employment and in necessitous circumstances." The Plan provided for four categories of instruction: 1) training projects of an occupational nature; 2) 'learnership' courses in industry; 3) work projects to combine training with conservation and development of natural resources; and 4) physical training programs to maintain health and morale. Participants were to be selected "without discrimination or favour with regard to racial origin, religious beliefs or political affiliations." ${ }^{24}$ Although sex discrimination is not specified, women, constituting $42 \%(23,156 \text { of } 55,457)^{25}$ of the total number of trainees, did not experience significant discrimination in being accepted for training. However, in terms of training offered, the situation was different. Women were excluded entirely from courses, which prepared students for work in mining and forestry. They attended, instead, those programs, which taught the tasks and skills considered appropriate for women in such sex-typed areas as homemaking, handicrafts, dress making, catering for tourists, stenography, waitressing, retail service, home nursing, and interior decorating. To prepare them for industrial work, women learned how to operate power sewing machines, thus fitting them for an occupation that also had been sex-typed as appropriate for women. ${ }^{26}$

In 1939, the Dominion-Provincial Youth Training Plan came under the Youth Training Act. Under the terms of this act, \$1,500,000 a year was set aside for a period of three years to be paid to provinces entering into agreements with the federal government for the purpose of training young men and women between the ages of 16 and 30 who were not gainfully employed and whose families were not in a position to pay the full cost of their training. The purposes of the Youth Training Plan were to fit unemployed young people for employment by 1) providing theoretical and technical instruction, as well as practical work experience; 2) improving their physical fitness; and 3) maintaining morale and instilling work habits and a sense of discipline. ${ }^{27}$ By July of 1940 , as the Second World War intensified, the demand for Canadian industrial output had grown but the availability of people with the necessary training had not. In response, Norman A. McLarty, Minister of Labour, solicited the cooperation of technical schools and universities and established three-monthlong summer courses to give pre-employment instruction for general production workers and machine operators. These courses, providing a minimum of 44 hours of instruction per week, were undertaken with close cooperation between provincial authorities, instructors, and industry so that the classes and curriculum would best meet the needs of industry. ${ }^{28}$

Following the success of the summer program, in September 1940 vocational training for war production was formally added to the 1939 Youth Training Act. War production training was merged into the existing Dominion-Provincial Youth Training Plan, which subsequently became known as the Dominion-Provincial War Emergency Training Plan. Under this new plan, the emphasis shifted from the professional and physical development of the individual to the satisfaction of the demands of industry. Although officials of the WETP celebrated the fact that 
courses continued to provide students with transferable skills, they stressed that the object of the plan was to meet the needs of industry. ${ }^{29}$ The director of the WETP, A.W. Crawford, thus explicitly stated that the primary purpose of training was "to serve the needs of war industries, not to educate individuals." ${ }^{30}$ In consequence, courses were arranged and conducted in consultation with industry and they simulated as closely as possible actual work conditions. ${ }^{31}$ In the pre-employment courses, trainees received from 400 to 500 hours of intensive occupational instruction, the length of time determined by what trainees needed "to attain the degree of skill required for that occupation for which they (were) being trained." 32 H.H. Kerr, Ontario Regional Director of the WETP, outlined the five objectives of the training given in the pre-employment classes: "1) To impart the basic skills and knowledge which will enable a trainee to become more rapidly and efficiently adjusted when employed in the industry for which he is being trained...2) To make trainees more adaptable and receptive to discipline...; 3) To weed out those who are not likely to make efficient or satisfactory employees owing to their apparent lack of mechanical aptitude...4) To make the trainee 'safety conscious' and to follow safe practices when operating a machine...5) To develop in the trainee a correct mental attitude towards his work." 33

This use of the masculine pronoun was not inclusive of men and women. Initially, officials of the WETP explicitly identified unemployed men with the "requisite capacity to benefit from the training or to perform the work" as its target group. ${ }^{34}$ Indeed, as Minister of Labour Norman McLarty explained to Minister of Pensions and National Health Ian Mackenzie, in May 1941, "Up to the present time occupations for which women are being used in war industries are of a nature which require very little training and this training is being given in industry rather than in pre-employment classes established under the War Emergency Training Plan.”35 Only under certain conditions could women participate in the WETP, that is, "... where an individual employer asked that a group be trained for a specific occupation in which the employer agreed to furnish employment to those who satisfactorily completed the course." ${ }^{36}$ In the first four months of 1941, only Ontario offered training to women and even then the number was small: only $2.7 \%$ or 271 women out of a total enrolment of $10,156 .{ }^{37}$ As of September 1941, Ontario was still the only province to have trained women. During the summer months, however, the numbers had risen to 1,343 , “....about $60 \%$ of whom were trained in power sewing machine operating." 38 By the end of 1941, the WETP reported that "women [were] being trained in increasing numbers as the supply of suitable men [had] rapidly diminished in many areas. During the calendar year 1941 training was given to 3,341 women or approximately $10 \%$ of the total number of trainees. On December $31^{\text {st }}$, 1941 women constituted about $17 \%$ of the total industrial enrolment..." ${ }^{39}$ By the end of December 1942, women constituted $48 \%$ of the pre-employment trainees, or 11,579 of $24,032 .{ }^{40}$ As with the Dominion-Provincial Youth Training Plan, under the WETP, women did not receive the same training as men. H.H. Kerr explained that " $(\mathrm{t})$ he normal course for men lasts for approximately 3 months, but this may be extended for trades requiring a higher degree of skill. Most women are trained as 
machine operators only and hence their courses are much shorter, frequently two or three weeks." ${ }^{41}$ But when the task to be performed by women required it, the WETP sponsored longer courses. This was the case with the female chemistry laboratory technician courses offered at the University of Western Ontario, three of which lasted six months and one of which lasted two months.

\section{Recruiting Female Chemistry Laboratory Technician Trainees}

Potential candidates learned of Western's female chemistry laboratory technicians' courses in a number of different ways. Some learned of it through word of mouth. Others found out about the course via a circular distributed by Dr. Gunton to the various high schools in southwestern Ontario. Still others read of the course in news reports carried in a variety of local southwestern Ontario newspapers announcing the establishment of the courses and the resulting graduation of its students. ${ }^{42}$ Because these written materials employed a discourse that might reasonably be expected to have been echoed by the young women in their letters of application and confirmation of attendance, I will consider them in some detail.

Because they were promoting a course sponsored by the WETP, the authors of the circular and the news reports emphasized the industrial demand for female chemistry laboratory technicians as well as the practical nature of the training to prepare the students to satisfy it. For example, the circular said that the course "will generate a general chemical technique so that the trainee may fit into routine laboratory work in any one of several industries, such as synthetic rubber, war chemicals, explosives or the Inspection Service. Emphasis will be placed on practical work rather than on theory, for the girls will be trained to do the jobs they will expect as their work when they assume positions." ${ }^{43}$ For its part, an article announcing the creation of the course in the London Evening Free Press was more specific. It noted that the "girls will learn the use of balance, the determination of moisture, specific gravity, composition of various mixtures through break-down of the mixture by chemical facilities such as filter papers and Gooch crucibles, the action of acids and bases. They will find out how to determine setting and melting points and preparation of standard solutions. In addition to the study under the chemistry department students will learn how to use a microscope and will be instructed in physical measurements by the department of physics." ${ }^{44}$ Another article published in the London Free Press on the first day of the course indicated that the twenty-five young women who had been selected from the more than 80 applicants, would, "[f] or six months...put in a 40-hour week at the university listening to five hours of lectures and spending 35 hours doing practical work in the laboratory to fit them for their ultimate positions in war industries." This article particularly emphasized the practical nature of the training, concluding with the sentence: "The course with its 35 hours of laboratory practice, stresses practical work rather than theory." ${ }^{25}$ In the ceremony that marked the graduation of this first class of female chemistry laboratory technicians, Regional Director H.H. Kerr found the opportunity to stress again that the WETP training had "taught [the young women] to work a 40-hour week, to observe working hours and to work according to 
regulations and to use their own initiative."46

While industrial demand and the practical nature of the training offered received a great deal of attention in both the circular and the news reports, the personal qualities of the desired students were also addressed. The circular, echoed by the news report announcing the creation of the course, stated that " $[\mathrm{k}]$ eenness and intelligence plus the desire to assist in making an all-out effort for the war are the chief requirements. It is desirable that applicants have higher matriculation standing in mathematics and science." The importance of patriotism and devotion to the war effort appeared again in the article that marked the graduation of the first class of female chemistry laboratory technicians. Regional Director H.H. Kerr who had spoken at the ceremony, called the young graduates "industrial soldiers...ready to take their places in the chemical battle." ${ }^{77}$ In a rather awkward passage, the article continues: "Mr. Kerr warned the graduates they would be 'letting your country down if you quit your job,' because they may think the hours too long, the wages not high enough for the work they are doing, the boarding facilities not satisfactory or because they may become lonesome far away from home. 'However bad your living conditions,' he concluded, 'they will not be nearly so bad as the conditions endured by the boys serving overseas. ${ }^{38}$ Another desired quality of applicants was youth. The circular thus read: "No age limit has been set, but it is hoped to draw from amongst recent high school graduates for the class members." Youth was favoured because of the mobility it afforded to the girls, who young and single, could be posted where their services were needed. Youth might also have been considered an attribute because of the belief that this would ensure a more docile and malleable workforce.

The financial considerations of the course and subsequent employment opportunities were also discussed in materials publicizing the course. The circular thus noted that as a course offered under the aegis of the WETP, not only was it free but also successful applicants would receive a subsistence allowance of $\$ 8.00$ a week. In the article reporting the graduation of the first class of female chemistry laboratory technicians, Dr. Gunton expressed support for the model established by the WETP: "University education in the future might benefit from the example of a subsidized and handpicked class such as this... [He] pointed out that most of the girls would not have gone to university unless they had been thus subsidized while in training and emphasized that by subsidizing students 'the ones who are entitled to an education' would receive it." He continued, "The university had not lost any of its dignity by introducing the training course for laboratory assistants... It had supplied a definite need." ${ }^{49}$ In terms of employment opportunities, the circular also indicated that "[p] ositions are not guaranteed but definite assurances have been given by several war industries, research establishments and the Inspection Board of the United Kingdom and Canada, that technical assistants are needed now in their laboratories and that this need will be even greater six months from now." And when employed, graduates could expect to be paid wages that ranged from $\$ 100$ a month in positions that offered "opportunity for advancement as chemical assistants."

What use did the young women make of these discourses in their letters? ${ }^{51}$ It is to this question that this study will now turn. 


\section{The Letters}

Teun A. van Dijk states that within a given context, and the expectations for a certain behaviour that it generates, discourse actors have to make choices about how to behave, about the discourse to employ. Further, when interacting with those with power, from whom something is desired, they must select the discourse or discourses that they believe will elicit the desired outcome. If they employ the wrong discourses, the outcome could be negative; they could be denied access to desired resources. ${ }^{52}$ Given the context studied here, I expected that the young women would have attempted to sell themselves to Dr. Gunton as excellent candidates for the female chemistry laboratory technician course. And I expected that they would do this by replicating the discourses found in the materials that publicized the program; they, after all, outlined the most desirable qualities sought in future trainees. The letters satisfied my expectations, but only to a degree. Many wrote of their academic qualifications. But few wrote of their desire to assist Canada's war effort, a surprise to me considering the prominence of this discourse in the recruitment materials and my perhaps naïve belief that all Canadians during the Second World War thought of nothing other than helping Canada's Total War effort. Less surprising to me, few echoed the discourse about the benefits offered by the practical nature of the course since that characteristic was intended more for the good of industry than for that of the young women. And only a few referenced the subsidized nature of the course as a reason for wanting to participate. Finally, showing a degree of independence and desire for personal achievement that I, again perhaps naïvely, did not anticipate, a few others introduced a new discourse of their own: their desire to benefit personally from the course both during and after the war.

\section{Scholastic Attainment}

As I anticipated, many (30) of the young women applicants emphasized that they had the necessary academic qualifications to undertake the chemistry laboratory technicians' course. This was a fundamental requirement. While some simply referred Dr. Gunton to their attached application form and certification of education, others went into greater detail. For example, Miss A. indicated that she had graduated with Junior Matriculation, a scholastic accomplishment that fitted her for the course, and Miss B. that she had completed her full Senior Matriculation. Standing in chemistry, or the lack of it, was discussed in the young women's letters of application, as well. One young woman noted that she had taken upper school chemistry but had not written an exam in the subject. ${ }^{53}$ Another indicated that she was "a student of Grade XIII of the Collegiate...At present my course includes Upper school Biology and Upper school Chemistry." ${ }^{54}$ Another, Miss B., indicated that she had completed her thirteen weeks of compulsory farm work and so secured her Senior Matriculation. In discussing their academic credentials, certain of the young women also emphasized their interest in chemistry and math. ${ }^{55}$ Thus Miss M. wrote, "I have all my middle school subjects and standing in the following upper school subjects...I am nineteen and throughout my course science has been my most interesting subject." 56 
Several of the young women explained why their unique qualifications, particularly their current laboratory employment or exposure to laboratory practices fit them for the course. Thus Miss L. noted that she had seven years experience in clinical laboratory routine and hoped that this experience would "perhaps prove of some value as a foundation" for the course. ${ }^{57}$ Another, who was employed in a laboratory testing waxes and varnishes, referred to this work experience as a way to compensate for what she perceived to be an academic deficiency: although she had senior matriculation, she had only junior matriculation in chemistry. ${ }^{58}$ For her part, Miss L. from Imperial Oil stated, "I'm very anxious to take this course as I'm now working in this type of work and want to learn more. A large synthetic rubber plant is being built here and I'm sure I'd be able to put this training to a practical use." ${ }^{59}$ And Miss O. wrote that she had completed a year's nursing training but that she had been forced to withdraw because of illness. She continued: "During my convalescence in the hospital I became greatly interested in laboratory work, and so am most anxious to enroll in this course and feel I would be most suited to it." ${ }^{60}$

A small number of young women approached the subject of academic achievement from the opposite position. They hoped that taking the female chemistry laboratory technician course would count towards their Senior Matriculation. Thus, Miss A. wrote that she wished to take the course but that to get her Senior Matriculation, she was required to provide thirteen weeks labour in Farm Service work. She and another two young women on whose behalf she was also writing wished to know if taking the chemistry laboratory technicians' course would count toward their senior matriculation because it led to vital war work. Dr. Gunton replied that the government did not allow this. He encouraged her to do what was necessary to obtain her Senior Matriculation so that she would not damage her post-war prospects for further education. After conferring with her parents and her high school principal, however, Miss A. asked to be considered for the course and was accepted. ${ }^{61}$

\section{War Effort}

Although the material publicizing the courses stated that desirable candidates should be intent on making an "all-out" contribution to the war effort, only eight of the successful applicants employed this discourse in their covering letters of application or in their letter acknowledging acceptance. Wrote Miss B., echoing exactly the discourse provided to her: "I would like to assist in an all-out effort for the war and I think that through this course I could best serve my country." For her part, another Miss B. wrote, "I am anxious not only to help the war effort if I can, but to qualify for the practical work as laboratory assistant in Chemical Industry." ${ }^{62}$ Miss E., whose employer, the Welland Chemical Works, recommended her for the course, wrote: "I think this course is an excellent means whereby I can extend my knowledge, and an ideal opportunity to help win the war!" ${ }^{63}$ Miss F. confided in Dr. Gunton: "Your course appeals to me very much as I have always been interested in Science. Since leaving school, I have worked in an office but now feel that I am marking time and wish to change to something which will make me more useful to my country." ${ }^{64}$ Along the same vein, Miss M. wrote, "I have always been interested in science and 
realize that this is a wonderful opportunity. At present I do not feel that I am doing enough for Canada's war effort, and would appreciate an opportunity to do my part." ${ }^{65}$ And Miss H., who applied to the course twice before gaining acceptance, wrote of her desire to support the war effort both times. On the first occasion, she wrote: "I am very interested in this type of work which would be based on mathematics and science, especially as it is connected with essential war work." In her second letter, she was even more emphatic: "I am very anxious to attend this course as I am very eager to do something in the war effort." Miss $\mathrm{H}$. highlighted the fact that her brother not only held a degree in chemistry but also had enlisted in the "Special Branch of the Royal Navy." "6r In trying to understand the women's decision to not replicate the discourse of war service, I looked to see if there was change over time. There was none; the young women did not become more or less concerned with contributing to the war effort between 1942 and 1944. They either simply did not feel a need to help Canada's war effort or they did not believe it necessary to mention it.

\section{Financial Limitations}

The various sources of information about the female chemistry laboratory technician course noted the fact that the course, as part of the WETP, was subsidized. Because the majority of the young women came from comfortable, if not affluent backgrounds, only six of the successful applicants to the four courses identified this as a reason to explain why they sought acceptance. Experiencing financial hardship, these young women explained that the only reason that they could take the course was because no tuition was charged and a living allowance was paid. For example, Miss T. wrote that she was anxious to take the first chemistry laboratory technicians' course because she was "financially unable to continue with the maths course that [she] had hoped to take." ${ }^{67}$ Miss W., accepted into the fourth course, wrote frankly to Dr. Gunton: "I would not be able to attend the regular courses at University because of the expense, and the free tuition of this special course would be a wonderful help. I have always been keenly interested in science and am looking forward to the time when I can really go to work in some phase of it." ${ }^{68}$ For her part, Miss D. had asked to "know of the approximate cost of the course as soon as possible." ${ }^{69}$ Was her concern to receive this information due to limited finances? I cannot confirm this but I suspect that this was the case. Miss B. was similarly circumspect in her language. Writing to express interest in attending the first course, she asked if she could take it extramurally because she was "employed at the Huron and Erie [Mortgage Corporation] and due to family obligations [could not] give up [her] position for a period of six months." That her family obligations were financial in nature was confirmed in a separate letter. A Mr. H. indicated that Miss B. was the sole support of her widowed mother. Her deceased father had been a member of the Grand Lodge and, following his death, his widow had been receiving financial aid from that organization. At her current job, Miss B. was receiving $\$ 17.50$ a week but as a graduate of Western's chemistry laboratory technicians' course she would earn significantly more and so relieve the Lodge of the financial obligation it had accepted. However, since the WETP only paid an allowance of $\$ 13$ to students with families to support, Miss B. required 
a subsidy to carry her through the six months of the course. The Grand Lodge agreed to provide this money and Miss $\mathrm{B}$. completed the second course. ${ }^{70}$

\section{Career Opportunity}

As is already apparent, some young women emphasized their interest in science or math as well as in undertaking the work of chemistry laboratory technician. Five young women went even further, writing that they saw the female chemistry laboratory technician course as providing a route to a career opportunity. They hoped the training they received would lead to permanent post-war employment. As such, Miss M., who eventually enrolled in the fourth course, asked Dr. Gunton several questions in her letter of application: "In becoming laboratory assistants have we a choice of positions when we are finished, or is there some placement system? Would the jobs be permanent? In this line of work is there much opportunity for advancement?" Gunton replied: "At the completion of the course there is a choice of location from which the trainee may select the one which pleases them the most. The positions in the war industries are likely to terminate at the end of the war but one or two industries such as Synthetic Rubber and certain chemicals will probably continue. There is an opportunity for advancement in all of these war industries." ${ }^{\text {"1 }}$ Miss W., who also attended the fourth course, had similar concerns: "I am also worried about the demand for scientific workers. Someone has suggested to me that if the war suddenly ended, this course would stop and I would be minus my Senior Matriculation, with no prospects of a job. Even if I complete the course before the end of the war, will there be sufficient demand for workers of that kind to employ all the graduates of the course? Do the sponsors of the course, - government or whoever it may be - do they find a position for each graduate, or is that left up to each person?" Again, Dr. Gunton responded to all of the questions as best he could: "It would be best in your case to continue and secure your upper school so as to be better qualified in case another course is offered and your services required. We would prefer that the applicants for the course be about eighteen years of age and have secured their upper school mathematics and science. The demand at present is good but there is no way of assuring how long that will continue or as to the circumstances after the war. Our course is strictly a war emergency project and it is not likely it will continue after the need ceases." ${ }^{\prime 2}$ For her part, Miss A. wrote: “...I am extremely interested in preparing myself for a career in the Plastics or similar industry..."73 For some young women, at least, the opportunity to train to become a chemistry laboratory technician was a route to satisfying post-war employment.

\section{Conclusion}

The cache of letters preserved by Dr. Gunton has provided a fascinating glimpse into the attitudes and motivations of an undeniably unique group of young women who trained as female chemistry laboratory technicians during the Second World War. Learning of the opportunity to attend this course from a variety of media, they chose among the different discourses provided to them in crafting their letters of 
application. Some of their choices were unsurprising. Many spoke of their academic credentials, correctly identifying this as one of the most important determinants of success. And only a few referenced financial need, a reflection of their family backgrounds. On the other hand, some of their choices were much more surprising. I had expected the majority to write of their desire to aid the war effort. After all, it was emphasized in the various written recruitment materials. As well, this commitment was not measurable with a diploma or other formal piece of paper. To have highlighted their patriotic fervour seemed to me to have been an easy and automatic element to have added to a letter of application. Perhaps the young women felt it went without saying. Or perhaps they remained relatively untouched by the war. This is a question to pursue in future research. Finally, a few of the young women were as concerned, if not more concerned, about their future, post-war employment than they were about filling a wartime need. I am not surprised that the young women thought that way but I am surprised that they wrote about it.

The letters explored in this study reflect the attitudes and motivations of a small group of young women. And it would certainly have been intriguing to have been able to compare them with the letters written by young women who were not accepted into the program. How did their letters differ? Was it purely academic credentials that secured the successful young women's acceptance? Or did the successful applicants address Dr. Gunton in a way that appealed to him, even with their limited use of the discourses provided to them by the recruitment materials? Unfortunately, these questions cannot be answered. However, the letters that do exist still provide interesting insights into the wartime experiences, attitudes, and motivations of a fascinating group of young women. Ultimately, the female chemistry laboratory course provided a rewarding employment opportunity to the young women, something also captured in women's letters, for more than one kept in touch with Dr. Gunton after their graduation. Miss A. thus wrote: "The work at the Plant is most interesting and we are just beginning to realize how much good that course did us." " I'm going to give the final word to Miss M.: "Dr. Gunton, I should like to thank you for your great kindness in making it possible for me to take the course. I enjoyed immensely both the good fellowship among the girls and the work itself which proved to be extremely interesting and exciting. Our class was given the most generous attention by the professors; and I know that all the students appreciated the wonderful privileges extended to them, and will be ever grateful to you." 75

\section{Notes}

1 University of Western Ontario Archives and Research Collections Centre (UWOA), War Emergency Training Records, A06-035, files "A" and "M." To protect the anonymity of the women, I am using last initial only.

2 The first, from September 1942 to March 1943, the second from April to September 1943, and the fourth, from September 1943 to March 1944, lasted for six months. The third course, running from July to September 1943, was of two months duration. 
3 See, for example, Máire Cross and Caroline Bland, "Gender Politics: Breathing New Life into Old Letters," in Gender and Politics in the Age of Letter-Writing, 1750-2000 (Aldershot, Hants, England and Burlington, VT: Ashgate, 2004), 7; Christa Hämmerle, "Requests, Complaints, Demands: Preliminary Thoughts on the Petitioning Letters of Lower-Class Austrian Women, 1865-1918," in Gender and Politics, eds., Máire Cross and Caroline Bland, 128-9;

4 Cross and Bland, "Gender Politics," 8.

5 Caroline Bland, "'In Case the Worst Comes to the Worst': Letters Home from Berlin, 1942-1945," in Máire Cross and Caroline Bland, eds., Gender and Politics, 226-7.

6 Cross and Bland, 8.

7 Rebecca Earle, "Introduction: Letters, Writers, and the Historian," in ed., Rebecca Earle, Epistolary Selves: Letters and Letter-Writers, 1600-1945 (Aldershot, Hants, and Brookfield, VT: Ashgate, 1999), 1-3; Susan M. Fitzmaurice, "Diplomatic Business: Information, Power, and Persuasion in Later Modern English Diplomatic Correspondence," in eds., Marina Dossena and Susan M. Fitzmaurice, Business and Official Correspondence: Historical Investigations (Bern: Peter Lang, 2006), 77.

8 Teun A. van Dijk, "Discourse as Interaction in Society," in ed., Teun A. van Dijk, Discourse as Social Interaction, Discourse Studies 2: A Multidisciplinary Introduction (London, Thousand Oaks, New Delhi: Sage Publications, 1997), 11.

9 van Dijk, "Discourse as Interaction in Society," 12.

10 van Dijk, 15.

11 Ibid, 16.

12 In applying for the course, the young women had been required to fill out an application form that asked questions about education. For this reason, 32 young women did not mention the level of schooling they had completed in what was essentially their cover letter. However, of the 103 files, only two contained a completed form. As well, no educational information was provided for the 15 who had been sponsored by the St. Clair Processing Corporation to take the third chemistry laboratory technician course.

13 I recognize that using the father's occupation to determine women's social class is problematic because it ignores women's own social, cultural, and intellectual capital. In the literature; however, the majority of theorists criticize the use of a husband's occupation to determine his wife's class position. It does not address the situation of daughters. Because I am looking at daughters most of whom were preparing to work for the first time in their lives and whose education was limited by their age, their father's occupation is still the best indicator of their social class. See, for example, Joan Acker, "Women and Social Stratification: A Case of Intellectual Sexism," The American Journal of Sociology, 78, 4 (January 1973): 936-945; Pamela Abbott and Roger Sapsford, Women and Social Class (London and New York: Tavistock Publications), 1987; Annemette Sørensen, "Women, Family, and Class," Annual Review of Sociology, 20 (1994): 27 47; Rosemary Crompton, Class and Stratification: An Introduction to Current Debates (Cambridge: Polity Press, 1993), 93-7; Norman Bonney, "Gender, Household and Social Class," British Journal of Sociology, 39, 1 (March 1998): 28-46.

14 I chose to use the 1947 prestige scale because of its proximity in time to the young women's lived experience. I suggest that it most closely reflects their opinions about their own family's status as well as that of Dr. Gunton. Robert W. Hodge, Paul M. Siegel, and Peter H. Rossi, "Occupational Prestige in the United States, 1925-1963," American Journal of Sociology, 70, 3 (November 1964): 291-92. See also, Rosemary Crompton, Class and Stratification, 55-58; Donald J. Treiman, "A Standard Occupational Prestige Scale for Use with Historical Data," The Journal of Interdisciplinary History, 7, 2 (Autumn 1976): 283-304; John Porter, The Vertical Mosaic: An Analysis of Social Class and Power in Canada (Toronto: University of Toronto Press, 1965), 9-11, 14-15. 
15 UWOA, War Emergency Training Records, 1942-43 (A06-035), file "S."

16 Christopher Willis, "Brief History of the Chemistry Department," 18 July 2008. http:// www.uwo.ca/chem/aboutus/depthistory.htm (Accessed 17 November 2011).

17 Hodge et al, "Occupational Prestige in the United States, 1925-1963," 290.

18 F.H. Leacy, ed., Series D107-D122, Historical Statistics of Canada, $2^{\text {nd }}$ ed., Ottawa: Statistics Canada, 1983, http://www.statcan.gc.ca/cgi-bin/af-fdr. cgi?l=eng\&loc=D107_122-eng.csv (Accessed, 17 February 2010).

19 Veronica Strong-Boag, The New Day Recalled: Lives of Girls and Women in English Canada, 1919-1939 (Markham: Penguin Books, 1988), 43.

20 Sally M. Horrocks, "A Promising Pioneer Profession? Women in Industrial Chemistry in Inter-War Britain," British Journal for the History of Science, 33 (2000): 352.

21 Peter Twohig, Labour in the Laboratory: Medical Laboratory Workers in the Maritimes, 1900-1950 (Montreal: McGill-Queen's Press), 2005.

22 Author, 2002.

23 The federal government assisted provincial governments in the provision of vocational education through the Agriculture Aid Act, 1912, the Agricultural Instruction Act, 1913, the Technical Education Act, 1919, and the Vocational Education Act, 1931. See, John E. Lyons, Bikkar S. Randhawa, and Neil E. Paulson, "The Development of Vocational Education in Canada," Canadian Journal of Education, 16, 2 (1991): 141-2; Darius Young, An Historical Survey of Vocational Education in Canada (Ottawa: Canadian Vocational Association, 1973), 26-7; J. Donald Wilson, Robert M. Stamp, and LouisPhilippe Audet, Canadian Education: A History (Scarborough, ON: Prentice-Hall of Canada, Ltd., 1970), 380, 454-5.

24 "Dominion-Provincial Youth Training in 1937," Labour Gazette, (June 1938): 616-7.

25 "Dominion-Provincial Youth Training in 1937," 616-7.

26 "Review of Dominion-Provincial Youth Training Program," Labour Gazette, (January 1938): 28-9; Ruth Roach Pierson and Marjorie Cohen, "Educating Women for Work: Government Training Programs for Women before, during, and after World War II," in eds., Michael S. Cross and Gregory S. Kealey, Modern Canada 1930-1980s: Readings in Canadian Social History Volume 5 (Toronto: McClelland and Steward, 1984), 208-10.

27 "Labour Legislation Enacted by the $4^{\text {th }}$ Parliament of Canada in 1939," Labour Gazette, (July 1939): 667-70; Montreal Labour World, September 1941.

28 "Vocational Training for War Production: Dominion-Provincial Co-operation in Establishing Special Summer Courses in Technical Schools," Labour Gazette, (July 1940): 680-1.

29 Jennifer A. Stephen, Pick One Intelligent Girl: Employability, Domesticity, and the Gendering of Canada's Welfare State, 1939-1947 (Toronto: University of Toronto Press, 2006), 56.

30 Library and Archives Canada (LAC), RG 27, Vol. 8-9-74, v. 1, A.W. Crawford, 'Memorandum for Labour Co-ordination Committee Re: Training of Industrial Workers,' 24 July 1941: 27.

31 The WEPT offered two types of courses: Training for Industry and Training for the Armed Forces. Under the former, it offered pre-employment courses, part-time courses, post-employment training in plant schools, and foremanship courses. Under the latter, it offered pre-enlistment courses for the R.C.A.F., training of men for the Royal Canadian Navy, and phase II training for Army Tradesmen.

32 LAC, RG 27, v. 701, File Y 12-2-6 (Section 8), H.H. Kerr, "The Dominion-

Provincial War Emergency Training Programme (A paper presented to the $23^{\text {rd }}$ Annual Convention of the Urban School Trustees' Association of the Province of Ontario)," 5.

33 LAC, RG 27, v. 701, File Y 12-2-6 (Section 8), H.H. Kerr, "The Dominion-

Provincial War Emergency Training Programme (A paper presented to the $23^{\text {rd }}$ Annual Convention of the Urban School Trustees' Association of the Province of Ontario)," 6-8. 
34 Labour Gazette, (January 1941): 17.

35 LAC, RG 27, v. 3533, File 3-26-41, pt. I, "Administration: Suggestions and Representations re: Training - General Correspondence," McLarty to Mackenzie, 2 May 1941. Women's training opportunities were affected by the tension between the fact that WETP courses could provide skills transferrable to the post-war employment market and two fundamental beliefs about women and work. These beliefs were, first, that women lacked mechanical aptitude, and, second, that they did not have a longterm commitment to the labour force. Both of these attitudes justified and explained the level of training offered to women. Through a process of "skills dilution," adopted as a means to "incorporate the female reserve into the war economy," women were trained to perform particular tasks rather than to understand a trade. While deskilling, an "inevitable by-product of economic and technological modernization," pre-dated the Second World War, "skills dilution" in the context of the war had distinctly gendered overtones. See, Stephen, Pick One Intelligent Girl, 33, 57-61; Pierson and Cohen, "Educating Women for Work," 218.

36 See also, "Vocational Training for War Production: Dominion-Provincial Co-operation in Establishing Special Summer Courses in Technical Schools," Labour Gazette, (July 1940): 680-1.

37 Labour Gazette, (May 1941): 571.

38 LAC, RG 27, v. 1273, File 2-Training Women (1941), "Dominion-Provincial Youth Training and War Emergency Training Program," Montreal Labour World, 27 September 1941.

39 LAC, RG 27, v. 725, file 12-2-1, "Progress Statement on Training Programme, April $1^{\text {st }}$ to December 31 $1^{\text {st }}$, 1941."

40 Pierson and Cohen, 216.

41 LAC, RG 27, v. 701, File Y 12-2-6 (Section 8), H.H. Kerr, "The Dominion-Provincial War Emergency Training Programme," 5.

42 In their letters of application, young women mentioned having seen articles in the London Free Press, the Windsor Daily Star, the Stratford Beacon-Herald, the Simcoe Reformer, the Kitchener Daily Record, and the Brantford Expositor.

43 UWOA, "War Emergency Training Records, 1942-43," (A06-035).

44 "Western to Train Women," London Evening Free Press, 22 August 1942, 15. General Chemistry and Elementary Analysis (Qualitative and Quantitative) - 200 hours; Mathematical Preparation - 15 hours; Organic Chemistry - 188 hours; Advanced Analysis - 300 hours; Physical Chemistry and Instrumental Analysis - 144 hours; Physical Measurements and Use of Tools - 20 hours; Light - 24 hours; Library Science - 15 hours'; Glass Working - 30 hours; First Aid and Safety, St. John's Ambulance Association - 24 hours.

45 "25 Girls Enrolled in Technicians' Course at University Here," London Daily Free Press, 16 September 1942, 1.

46 Ibid.

47 Ibid.

48 "Class of Girls Graduated as Laboratory Technicians," London Free Press, 13 March 1943, 3.

49 "Class of Girls Graduated as Laboratory Technicians," London Evening Free Press, 13 March 1943, 3.

50 UWOA, "War Emergency Training Records, 1942-43," (A06-035).

51 While Dr. Gunton had created files for the 103 young women accepted into the program, those files varied in content: there were 68 covering letters of application and 44 letters acknowledging acceptance and confirming attendance. The former, the covering letters of application are the richer source for exploring the discourses employed by the young women seeking to be accepted into the course. However, I have included the letters of confirmation of attendance in my sample because several of them echo the language of the recruitment materials, as well. 
52 van Dijk, "Discourse as Interaction in Society," 18.

53 UWOA, "War Emergency Training Records, 1942-43," (A06-035), file "P."

54 UWOA, "War Emergency Training Records, 1942-43," (A06-035), file "G."

55 UWOA, "War Emergency Training Records, 1942-43," (A06-035), file "B."

56 UWOA, "War Emergency Training Records, 1942-43," (A06-035), file "M."

57 UWOA, "War Emergency Training Records, 1942-43," (A06-035), file "L."

58 UWOA, "War Emergency Training Records, 1942-43," (A06-035), file "M."

59 UWOA, "War Emergency Training Records, 1942-43," (A06-035), file "L."

60 UWOA, "War Emergency Training Records, 1942-43," (A06-035), file "O."

61 UWOA, "War Emergency Training Records, 1942-43," (A06-035), file "A."

62 UWOA, "War Emergency Training Records, 1942-43," (A06-035), file "B."

63 UWOA, "War Emergency Training Records, 1942-43," (A06-035), file "E."

64 UWOA, "War Emergency Training Records, 1942-43," (A06-035), file "F."

65 UWOA, "War Emergency Training Records, 1942-43," (A06-035), file "M."

66 UWOA, "War Emergency Training Records, 1942-43," (A06-035), file "H."

67 UWOA, "War Emergency Training Records, 1942-43," (A06-035), file "T."

68 UWOA, "War Emergency Training Records, 1942-43," (A06-035), file "W."

69 UWOA, "War Emergency Training Records, 1942-43," (A06-035), file "D."

70 UWOA, "War Emergency Training Records, 1942-43," (A06-035), file "B."

71 UWOA, "War Emergency Training Records, 1942-43," (A06-035), file "M."

72 UWOA, "War Emergency Training Records, 1942-43," (A06-035), file "W."

73 UWOA, "War Emergency Training Records, 1942-43," (A06-035), file "A."

74 UWOA, "War Emergency Training Records, 1942-43," (A06-035), file "A."

75 UWOA, "War Emergency Training Records, 1942-43," (A06-035), file "M." 